\title{
DIABETES INSIPIDUS FOLLOWING TUBERCULOUS MENINGITIS
}

\author{
BY \\ JOHN LORBER \\ From the Department of Child Health, University of Sheffield
}

(RECEIVED FOR PUBLICATION JANUARY 27, 1958)

In tuberculous meningitis the site of the maximal infection and of the most dense exudate is the basal cisterns, particularly the cisterna chiasmatis and the cisterna ambiens. This exudate may lead to obstruction of the cerebrospinal fluid pathways, which can be readily demonstrated by pneumoencephalograms (Lorber, 1951). Calcification of this exudate occurs in a large proportion of children who recover from the diseaseand can be shown two or three years after the onset of the meningitis on radiographs of the skull (Lorber, 1952; Lorber, 1958). These lesions are in close proximity to the pituitary gland and the hypothalamic nuclei. They may lead to vascular thromboses and consequently to softening of the adjacent brain substance. Furthermore, the hypothalamic nuclei may suffer as a consequence of the variable degrees of hydrocephalus produced by the obstruction of the cerebrospinal fluid.

In view of these very common developments it would be reasonable to expect endocrine sequelae to result from a disturbance of the posterior pituitaryhypothalamic mechanism. Of the endocrine disorders originating in this area diabetes insipidus is one of the best recognized examples.

Nevertheless, although by now thousands of patients must have survived tuberculous meningitis, reports of diabetes insipidus occurring as a complication during or after this illness are very few indeed (Table 1) and none of the reports furnished adequate proof of a true diabetes insipidus. All the reported cases had polyuria and polydipsia, and it is possible that full proof of diabetes insipidus was established in some of them by appropriate endocrinological tests, but these were not published. This certainly applies to the patient of Hooft and van Winckel (1957) about whom Professor Hooft kindly supplied fuller details in a personal communication which fully established the diagnosis of true pitressinsensitive diabetes insipidus. It is possible that the 11 cases briefly summarized in Table 1 are an incomplete list. The literature on tuberculous meningitis is so vast now that mention of some cases in papers not specifically dealing with endocrine sequelae or with follow-up studies may have escaped detection. The table does not include a few cases quoted by authors without details or quoting exact references. It is noteworthy that, with one exception (Acheson and Smith, 1958), none of the reported cases was in the British or American literature.

No case of diabetes insipidus has developed among 131 surviving children who were treated in the Children's Hospital, Sheffield, and who were followed for two to 10 years after their admission. We have, however, seen and investigated a child through the courtesy of Dr. J. S. Oldham, who referred him to us because of polyuria and polydipsia, and who was proved to have true diabetes insipidus.

\section{Case History}

R. was born on February 9, 1945, and was the oldest of three children. He weighed $7 \mathrm{lb}$. He contracted tuberculous meningitis in 1948 at the age of $3 \frac{1}{2}$ years and was treated with intramuscular and intrathecal streptomycin. The total duration of treatment was $\mathbf{7 5}$ days and during this time he received 40 intrathecal injections of $50 \mathrm{mg}$. each. Following this illness he was left with severe visual and hearing defects. He was almost blind in the left eye and had poor vision in his right eye. His left ear was almost deaf and his right ear was also affected. His mental development was normal and he attended ordinary schools, as no vacancy could be found for him in a school for partially-sighted children. His headmaster reported that in spite of his physical handicaps he successfully competed with his contemporaries in academic work and he would have been above the average but for his disabilities. According to the school records his height and weight were as follows:

\begin{tabular}{lcccccc}
\multicolumn{1}{c}{ Date } & & $\begin{array}{c}\text { Age } \\
\text { (yrs.) }\end{array}$ & & $\begin{array}{c}\text { Height } \\
\text { (in.) }\end{array}$ & & $\begin{array}{c}\text { Weight } \\
\text { (lb.) }\end{array}$ \\
4.10 .51 & $\ldots$ & $\mathbf{6} 8 / 12$ & $\ldots$ & $42 t$ & $\ldots$ & $\mathbf{4 3 1}$ \\
23.11 .53 & $\ldots$ & $\mathbf{8} 9 / 12$ & $\ldots$ & 47 & $\ldots$ & 51 \\
1.6 .56 & $\ldots$ & $114 / 12$ & $\ldots$ & 48 & $\ldots$ & 56
\end{tabular}

In February, 1957, at the age of 12 years, he was struck on the head by a football. He was dizzy, but was not 
TABLE 1

REPORTED CASES OF PRESUMED DIABETES INSIPIDUS FOLLOWING TUBERCULOUS MENINGITIS

\begin{tabular}{|c|c|c|c|c|c|c|c|}
\hline Author & $\begin{array}{c}\text { Number } \\
\text { of } \\
\text { Cases }\end{array}$ & $\begin{array}{c}\text { Age } \\
\text { (years) }\end{array}$ & $\begin{array}{l}\text { Onset related } \\
\text { to } \\
\text { Meningitis }\end{array}$ & $\begin{array}{l}\text { Other } \\
\text { neurological } \\
\text { Defects }\end{array}$ & $\begin{array}{l}\text { Other } \\
\text { endocrine } \\
\text { Defects }\end{array}$ & $\begin{array}{l}\text { Proof of } \\
\text { Diabetes } \\
\text { Insipidus }\end{array}$ & . Comments \\
\hline Asperger (1948) & 1 & Child & ? During meningitis & Multiple & - & Clinical only & Doubtful case \\
\hline Pinna (1953) & 1 & 8 & During meningitis & Died & - & $\begin{array}{c}\text { Clinical and } \\
\text { necropsy }\end{array}$ & \\
\hline $\begin{array}{l}\text { Conese, Colonna and } \\
\text { La Pesa (1954) }\end{array}$ & 1 & 25 & $\begin{array}{l}\text { Soon after } \\
\text { recovery }\end{array}$ & No details & - & $\begin{array}{l}\text { Polyuria and } \\
\text { polydipsia } \\
\text { urine } \\
\text { S.G. 1,002-4 }\end{array}$ & Not proven \\
\hline Kissel and Arnould (1954) & 1 & 24 & $\begin{array}{l}11 \mathrm{~m} \text {. after } \\
\text { recovery }\end{array}$ & + & - & Polyuria & $\begin{array}{l}\text { Recovery after } \\
\text { air encephalo- } \\
\text { gram }\end{array}$ \\
\hline Inglessi (1954) $\ldots$ & 1 & 14 & 3 yr. after recovery & - & $\begin{array}{l}\text { Sexual infantil- } \\
\text { ism }\end{array}$ & $\begin{array}{l}\text { Pitressin- } \\
\text { sensitive } \\
\text { Polyuria and } \\
\text { polydipsia }\end{array}$ & \\
\hline $\begin{array}{l}\text { Riser, Geraud, Ribaut, } \\
\text { Gleizes, Rascol and } \\
\text { Saint Marc (1955) }\end{array}$ & 1 & 24 & During treatment & - & Schizoid & Clinical & $\begin{array}{l}\text { Complete } \\
\text { recovery after } \\
2 \frac{1}{2} \text { yr. }\end{array}$ \\
\hline Post (1955) & 1 & Child & After recovery & No details & - & No details & \\
\hline Castel-Branco (1956) & 2 & $\begin{array}{l}7 \\
6\end{array}$ & $\begin{array}{l}\text { During meningitis } \\
3 \mathrm{~m} \text {. after onset }\end{array}$ & - & - & $\begin{array}{l}\text { Pitressin- } \\
\text { sensitive } \\
\text { Clinical }\end{array}$ & $\begin{array}{l}\text { Recovery after } \\
2 \text { yr. } \\
\text { Good response } \\
\text { to cortisone }\end{array}$ \\
\hline $\begin{array}{c}\text { Hooft and van Winckel } \\
\begin{array}{c}\text { (1957) } \ldots \\
\ldots\end{array}\end{array}$ & 1 & 6 & $4 \mathrm{~m}$. after recovery & - & - & $\begin{array}{l}\text { Proved by water } \\
\text { restriction } \\
\text { test* } \\
\text { Pitressin- } \\
\text { sensitive }\end{array}$ & \\
\hline Acheson and Smith (1958) & 1 & 10 & $62 \mathrm{~m}$. after onset & None & $\begin{array}{l}\text { Atrophy of left } \\
\text { testis (normal } \\
\text { puberty) }\end{array}$ & $\begin{array}{l}\text { Pitressin- } \\
\text { sensitive } \\
\text { Extreme } \\
\text { polyuria (S.G. } \\
1,000-6) \text { and } \\
\text { polydipsia }\end{array}$ & $\begin{array}{l}\text { Doing well on } \\
\text { pitressin } \\
\text { tannate } \\
\text { (S.G. 1,018-24) }\end{array}$ \\
\hline
\end{tabular}

* Personal communication.

rendered unconscious. During the following month he complained of headaches of increasing frequency and severity, but vomited only once before his admission to the Staincliffe General Hospital, Dewsbury, on March 6, 1957. On admission there he was found to have meningism and bilateral optic atrophy. The cerebrospinal fluid contained 106 white cells $/ \mathrm{ml}$. with $98 \%$ lymphocytes, protein $170 \mathrm{mg}$. \%, chlorides $730 \mathrm{mg} . \%$, and sugar $25 \mathrm{mg} . \%$. Acid and alcohol fast bacilli were seen in the deposit and were repeatedly found in the cerebrospinal fluid for nine days after admission. In due course tubercle bacilli were grown on culture and were recovered from inoculated guinea-pigs. His urine was persistently acid, had a specific gravity of 1,012 on two occasions, contained a trace of albumin and there were approximately 20 leucocytes per high power field in the deposit. Acid-alcohol fast bacilli were detected in several specimens of urine up to the end of April, 1957, and tubercle bacilli were cultured and recovered from inoculated guinea-pigs. The organism was resistant to $10 \mu \mathrm{g}$. and sensitive both to $30 \mu \mathrm{g}$. of streptomycin per $\mathrm{ml}$, , and to $5 \mu \mathrm{g}$. of isoniazid per $\mathrm{ml}$. A radiograph of the chest showed no lesion. A radiograph of the abdomen showed a dense calcified shadow at the level of the third lumbar vertebra, near the midline, but sometimes to the left and at another time to the right side, indicating that it was a calcified mesenteric lymph-node. A radiograph of the skull (Fig. 1) showed a dense crescentic calcification just below the posterior clinoid process of the sella at and slightly to the right of the midline.

The blood picture and blood urea were normal.

A diagnosis of a relapse of tuberculous meningitis was clinically, radiologically and bacteriologically established. An additional diagnosis of renal tuberculosis was made and this was confirmed later by an intravenous pyelogram (Fig. 2) which showed considerable right-sided hydronephrosis with a dilated and rigid right ureter. Cystoscopy was performed later and this showed inflammation around the right ureteric orifice. The orifice was depressed and was reminiscent of a 'golf hole ureter'. Catheterization of the left ureteric orifice was easy, but the catheter could not be passed into the right orifice. The urine from the left kidney gave a negative culture for tubercle bacilli.

Treatment. The treatment given was as follows: $1 \mathrm{~g}$. of intramuscular streptomycin daily; $100 \mathrm{mg}$. of intra- 
thecal streptomycin daily for 30 injections, followed by five injections in the next 11 days and followed again by daily injections for a further 16 days. (Total: eight weeks). Isoniazid was given orally in doses of $300 \mathrm{mg}$. daily from admission, and was started intrathecally in doses of $15 \mathrm{mg}$. daily a week later and continued for 18 injections. A second course of intrathecal isoniazid of 23 injections was given during the second month of treatment. In addition $5 \mathrm{mg}$. of hydrocortisone was given intrathecally daily from admission for 18 days and again during the third month from May 21 till June 10 for 21 injections. On stopping this $15 \mathrm{mg}$. of prednisolone was given by mouth

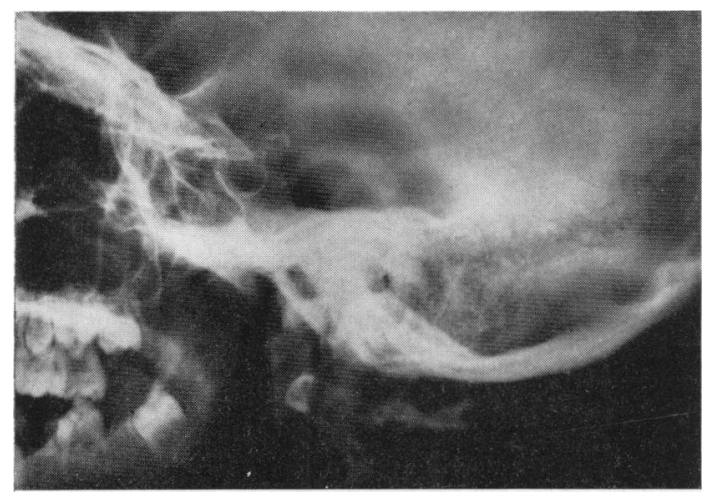

Fig. 1.-Radiograph of the skull showing calcification.

daily for 17 days, $10 \mathrm{mg}$. daily for eight days and $5 \mathrm{mg}$. daily for three days.

Progress. His condition slowly but steadily improved. He became more alert and lost his headaches. Occasional vomiting persisted for a few weeks but then ceased. The cerebrospinal fluid showed good improvement after the usual early fluctuations. At the end of May, 1957, it contained 11 white cells/c.mm., protein, $130 \mathrm{mg} . \%$ and sugar, $53 \mathrm{mg} . \%$. By July 20, 1957, three and a half months after admission, the cerebrospinal fluid sugar had risen to $67 \mathrm{mg}$. \% and he was thought to be well enough to go home for a holiday.

A single reading of the urinary specific gravity on July 11 had been only 1,002, and it was noted that he was drinking a great deal of water and had started to vomit water at night. He never vomited food. His urine was otherwise normal.

During his holiday at home his parents noticed increasing polydipsia and polyuria. His headaches returned and he now vomited frequently. He was readmitted to hospital on August 2, 1957, severely dehydrated. There was no deterioration in the neurological signs or in the cerebrospinal fluid, but he continued to vomit and developed a peripheral circulatory failure of such an extent that he required intravenous rehydration. During the next month he continued to drink large quantities of fluids averaging five to six pints daily and to pass even larger quantities of urine of the order of five to nine pints daily. The specific gravity was persistently very low but during a concentration test a single figure of 1,020 was obtained. At the same time the vomiting became incessant although findings in the cerebrospinal fluid remained fully satisfactory and there was no evidence of renal failure.

In view of these unfavourable developments he was transferred for further investigations to the Children's Hospital, Sheffield, on September 3, 1957. On admission his general condition was good. He was alert and

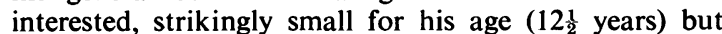
not thin. His standing height was $49 \frac{1}{2}$ in. (126 cm.).

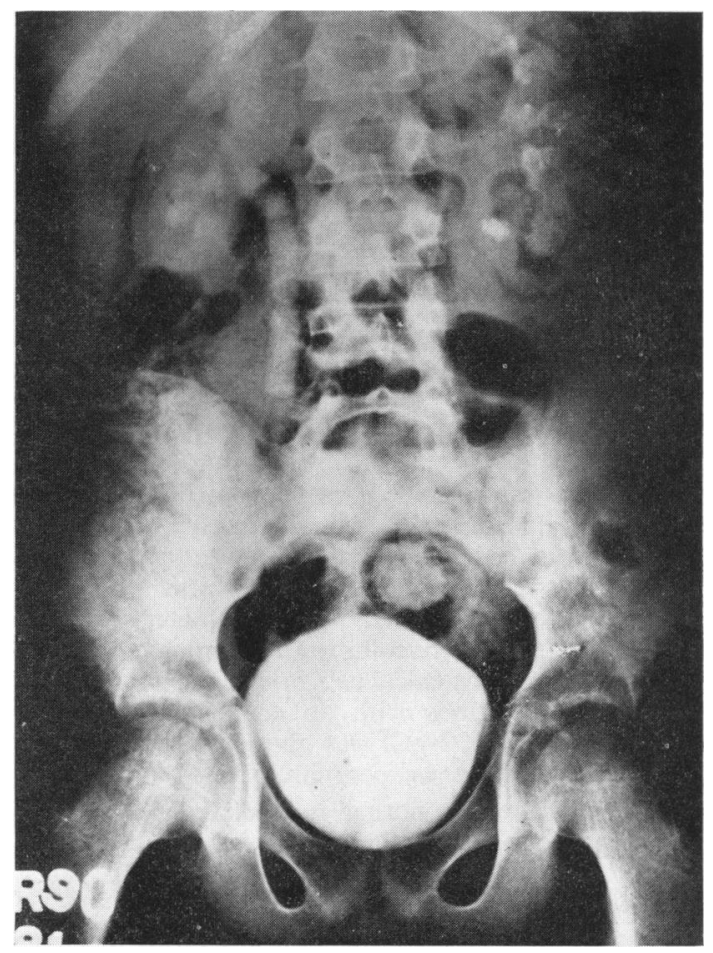

FIG. 2.-Intravenous pyelogram showing right-sided hydronephrosis.

His other anthropometric measurements were as follows: sitting height, $29 \frac{1}{2}$ in. ( $75 \mathrm{~cm}$.); crown to umbilicus, $20 \frac{1}{2}$ in. $\left(51 \mathrm{~cm}\right.$.); umbilicus to sole, 29 in. (74 cm.); span, $51 \frac{3}{4}$ in. (132 cm.). He weighed $60 \mathrm{lb}$. $(27.5 \mathrm{~kg}$.$) . Both his$ height and weight were below the third percentile for his age and corresponded to the 50 percentile of a boy of 7 years for height and 8 years for weight (Nelson, 1954). His penis and testicles were very small for his age and there were no secondary sexual characteristics.

The presence of bilateral optic atrophy and partial deafness was confirmed. Blood pressure was 120/80 $\mathrm{mm}$. Hg. There was no meningism.

Investigations. The cerebrospinal fluid showed slight abnormalities consistent with recent tuberculous menin- 
gitis (43 white cells, protein $55 \mathrm{mg} . \%$; sugar $41 \mathrm{mg} . \%$ ). His urine was normal chemically and microscopically and no tubercle bacilli were seen, cultured, or recovered from inoculation of guinea-pigs. The specific gravity, however, was persistently between 1,000 and 1,005 . There was no evidence of renal failure.

His visual acuity was $3 / 60$ on the right and there was light perception only on the left. The visual fields were not constricted. Electric audiometry showed a hearing loss of 30 to 40 decibels between frequencies of 128 and 2,048 on the right ear and 75 decibels on the left ear. The resting record of the electroencephalogram was normal but over-breathing produced an abnormally big build-up with dysrhythmic changes suggesting minimal, focal residual damage.

A radiograph of the skull confirmed the presence of the suprasellar calcification. An intravenous pyelogram showed a normal kidney outline on the left, but there was no visible secretion on the right. His bone age was between 7 and 8 years.

The polydipsia, polyuria and vomiting continued. $\mathrm{He}$ woke several times in the night to pass large quantities of urine, but he responded well to a trial of posterior pituitary snuff. As his polyuria could not be explained on a renal basis, the test recommended by Carter and Robbins (1947) (and modified from that of Hickey and Hare (1944)) was performed on September 10, 1957. (Fig. 3).

The test was performed as follows: fluids were withheld for eight hours preceding the test and then $20 \mathrm{ml}$. of water per $\mathrm{kg}$. of body weight were given by mouth over a period of one hour. Thirty minutes after the period of hydration was begun, an indwelling catheter was inserted. Urine specimens were collected in 15-minute periods and the urine flow was calculated in ml. per minute. After two control periods with an adequate urine flow, a solution of $2 \cdot 5 \% \mathrm{NaCl}$ was given intravenously at the rate of $0.25 \mathrm{ml}$. per $\mathrm{kg}$. per minute for 45 minutes.

Using this test on normal individuals or in those with psychogenic polyuria there is a marked reduction of urine flow beginning after 15 minutes. In cases of diabetes insipidus there is no response.

In the case of R. the urinary output during the first two 15-minute control periods was $5 \mathrm{ml}$. and $3 \mathrm{ml}$. per minute respectively. During the intravenous infusion of $2.5 \%$ saline there was no significant reduction in the rate of urinary flow whilst at the conclusion of the infusion and immediately after the rate rose to $8 \mathrm{ml}$. per minute. The specific gravity of the urine remained very low. The test showed conclusively that this was not a case of psychogenic or habit polyuria but true diabetes insipidus. He was then given an intravenous injection of $0.1 \mathrm{ml}$. of pitressin to find out whether the diabetes was of renal or pituitary origin. There was an immediate and gross reduction in the urinary output to $0.1 \mathrm{ml}$. per minute. The volume of this sample was too small for the estimation of the specific gravity, but that of the next sample was 1,012 (Fig. 3), showing that the diabetes insipidus was pitressin-sensitive and of pituitary-hypothalamic origin.
Treatment of the Diabetes Insipidus. Treatment was begun with pituitary snuff starting at first with one capsule in the evening and after two doses was continued with one capsule morning and evening. On this regime his fluid intake and urinary output fell by about one half and varied between two and three pints per 24 hours. The specific gravity of the urine frequently rose to 1,012 . This was not considered to be sufficiently good control, especially as he still woke up several times in the night, and therefore his treatment was changed to intramuscular pitressin tannate. The dose was gradually increased from $0.3 \mathrm{ml}$. on alternate days to $0.6 \mathrm{ml}$. daily. On the latter dose his fluid intake varied between 23 and $31 \mathrm{oz}$., and his urinary output between $15 \frac{1}{2}$ to $20 \mathrm{oz}$. daily. The specific gravity of the urine rose to 1,020 . He stopped vomiting.

He was discharged home on a maintenance dose of $0.6 \mathrm{ml}$. of pitressin tannate on alternate days.

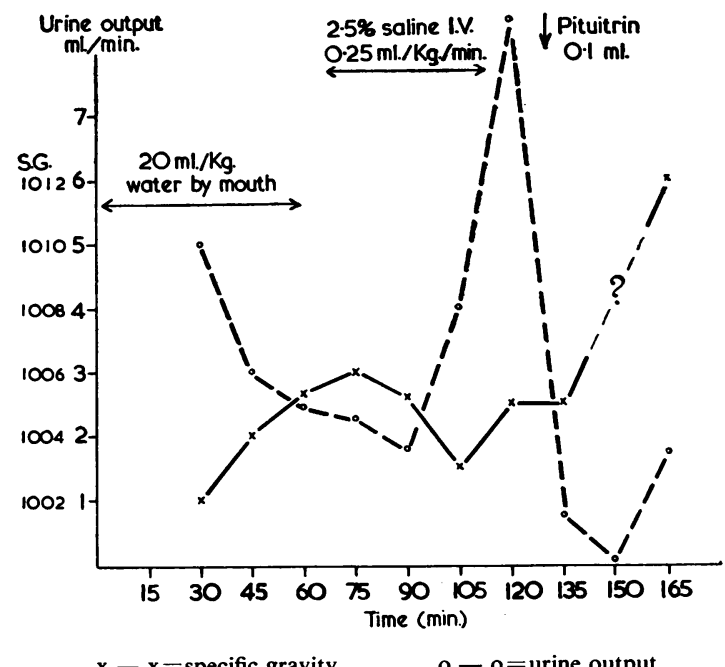

Fig. 3.-Result of Carter-Robbins test in a case of tuberculous meningitis followed by diabetes insipidus (10.9.57).

Family History. As it was apparent that this boy not only had diabetes insipidus but might be a pituitary dwarf with sexual infantilism, it was necessary to go into the family history with regard to stature and sexual development.

Both his parents were small. The father was $5 \mathrm{ft} .6 \frac{1}{2}$ in. tall $(169 \mathrm{~cm}$.) and his mother $4 \mathrm{ft} .11$ in. $(150 \mathrm{~cm}$.). His sister who was two years younger was just taller than $R$. The two grandfathers were $5 \mathrm{ft} .5 \mathrm{in} .(165 \mathrm{~cm}$.) and $5 \mathrm{ft}$. 3 in. $(160 \mathrm{~cm}$.) and his grandmothers $5 \mathrm{ft} .4$ in. $(162 \mathrm{~cm}$.) and $5 \mathrm{ft} .(152 \mathrm{~cm}$.) respectively. His maternal uncles and aunts were all of small build, but no measurements were available. The only available information regarding sexual development is that his mother's menarche was at $\mathbf{1 4}$ years and his maternal aunt's at $\mathbf{1 7}$ years. 


\section{Discussion}

The diagnosis of diabetes insipidus of pituitary and hypothalamic origin has been established beyond loubt in our patient. He is now making good progress on pitressin treatment. It is not clear, however, whether the diabetes insipidus is a very late sequel of his first attack of meningitis which healed by meningeal calcification, or is the result of his second attack. In the earlier reported cases of diabetes insipidus the onset was either during the active phase of the meningitis or after recovery, but in none of them was it delayed by more than three years. Taking these features as guidance it seems likely that in our patient the second attack was the precipitating factor, although it is probable that the damage resulting from the first attack paved the way for the development of the disorder. That damage to the hypothalamic-pituitary mechanism did occur as a result of the first attack is undoubted, not only because of the presence of intracranial calcification immediately above the sella turcica, but more so because of the considerable retardation of the boy's growth and skeletal maturation, and by his apparent sexual infantilism. The last feature is not yet adequately proven as he is not quite 13 years old. Sexual infantilism and dwarfism was noted by Inglessi (1954) in a boy who was 14 years of age at the onset of the meningitis, and $17 \frac{1}{2}$ when the diabetes insipidus developed.

Another interesting feature of diabetes insipidus following tuberculous meningitis is that it is apparently capable of spontaneous recovery. Three of the reported cases recovered completely two to two and a half years after the onset, but in none of these was the diagnosis of a true diabetes insipidus adequately established.

\section{Summary}

This is a case of a boy who survived two attacks of tuberculous meningitis. The first attack occurred at the age of $3 \frac{1}{2}$ and he recovered with no deterioration in his good intelligence, but with grossly diminished vision and hearing. Subsequently his physical growth became very slow. At the age of 12 he had another attack of tuberculous meningitis. During the fifth month of treatment he developed the typical symptoms of diabetes insipidus. This diagnosis was established by salt and water loading tests. Treatment with pitressin led to satisfactory control of his polyuria and polydipsia. At the age of 13 he has shown no evidence of any secondary sexual characteristics.

The literature relating to diabetes insipidus following tuberculous meningitis is reviewed and its great rarity is noted.

I wish to thank Dr. J. S. Oldham for referring this patient to us, Professor C. Hooft and Dr. Honor V. Smith for details of similar cases under their care and Professor R. S. Illingworth for his criticism.

\section{REFERENCES}

Acheson, R. M and Smith, Honor V. (1958), Ouart. J. Med., 27, 83 Asperger, H. (1948). Wien. klin. Wschr., 60, 845.

Carter, A. C. and Robbins, J. (1947). J. clin. Endocr., 7, 753.

Castel-Branco, N. (1956). Rev. ibér. Endocr., 3, 422.

Conese, G., Colonna, L. and La Pesa, M. (1954). Policlinico, $61,37$.

Hickey, R. C., and Hare, K. (1944). J. clin. Invest., 23, 768.

Hooft, C. and Winckel, H. van (1957). Maandschr. Kindergeneesk, '25, 280.

Inglessi, E. (1954). Arch. franc. Pédiat., 11, 621.

Kissel, P. and Arnould, G. (1954). Rev. neurol., 90, 812

Lorber, J. (1951). Arch. Dis. Childh., 26, 28. (1952). Ibid., 27, 542

- (1958). Amer. Rev. Tuberc. In the Press.

Nelson, W. E. (1954). Textbook of Pediatrics, 6th ed. Philadelphia.

Pinna, P. (1953). Ann. ital. Pediat., 6, 365.

Pinna, P. (1953). Ann. ital. Pediat, 6, 365.

Riser, M., Geraud, J., Ribaut, L., Gleizes, L., Rascol, A. and Saint Marc. (1955). 'Toulouse méd., 56, 429.

Smith, H. V. Personal communication. 